\title{
Food and agriculture model for Finland
}

\author{
LAURI KETTUNEN,
}

Agricultural Economics Research Institute, Rukkila, 00001 Helsinki 100

Abstract. The purpose of the project of the Finnish food model is

a) to examine what are the long term problems of Finnish agriculture

b) to build a mathematical model which can be used for the description of the development of agriculture and which includes policy factors which affect the development, and

c) to study what kind of policy actions are needed to secure selfsufficiency of agriculture in the long run.

The first version of the model is presented in this article. It is a recursive simulation model where only the use of fertilizer is determined by optimization methods. The base year is 1978 and the development of agriculture can be simulated 25 years ahead. The estimates of parameters are mainly obtained from previous studies, but in some cases subjective consideration is needed.

\section{Introduction}

The purpose of the Finnish food model is to describe the interrelationships of the various parts of agriculture and serve as a policy tool for decision-makers in long term policy assessment and planning. It is not intended primarily for prognostication but rather for simulation of different development paths when different policy targets are set or different policy actions are taken.

The model is designed to study the effects of different self-sufficiency targets on agricultural production and structure. It should also give information as to what kind of bottlenecks Finnish agriculture will face in the future: Is it the decline of the agricultural population or the per hectare yields, or the financial problems which will hamper the development and possibly the supply of food? Of course, the model will also give other kinds of information which is of interest to decision-makers, farmers or other parties concerned.

The model is built beginning from the present agricultural situation in Finland which has such characteristics as small farm size, excessive overproduction of animal production, large annual variations in crop yields, use by the agricultural sector of mainly imported energy and a prediction of generally slow economic development in the future. Quantification of the various interrelationships in agriculture is an important but difficult part of the project. The final output should be a model which could be used for the simulation of agricultural development under different assumptions. 
The model is also built so that it can be linked to the global model of the International Institute for Applied Systems Analysis (IIASA). The purpose of the IIASA's research project is to construct a system of national models which can be used for analysing the effects of the national policy actions on the world food situation (e.g. KEYZER 1977 and de HAEN 1978). The linkage of the Finnish food model to the IIASA's model is expected to give valuable information e.g. on the effect of the trend in world market prices on Finnish agriculture.

The structure of the Finnish food model is briefly described in Chapter 2. Figure 1 gives an overall picture of the model. It describes the linkage part of the model which can be used as such or supplemented by the agricultural sub-model which is described in the latter part of the article.

The construction of the model has gone through several phases but it is still called the first version since some alterations can be expected in the future.

The model is mainly recursive and only the version which is linked to the IIASA's system includes optimization sub-models. The pure simulation model has some drawbacks which have to be accepted in this phase of the model building.

The model consists of two sectors: agriculture and non-agriculture. The subscripts a and na are applied to indicate to which sector a variable belongs.

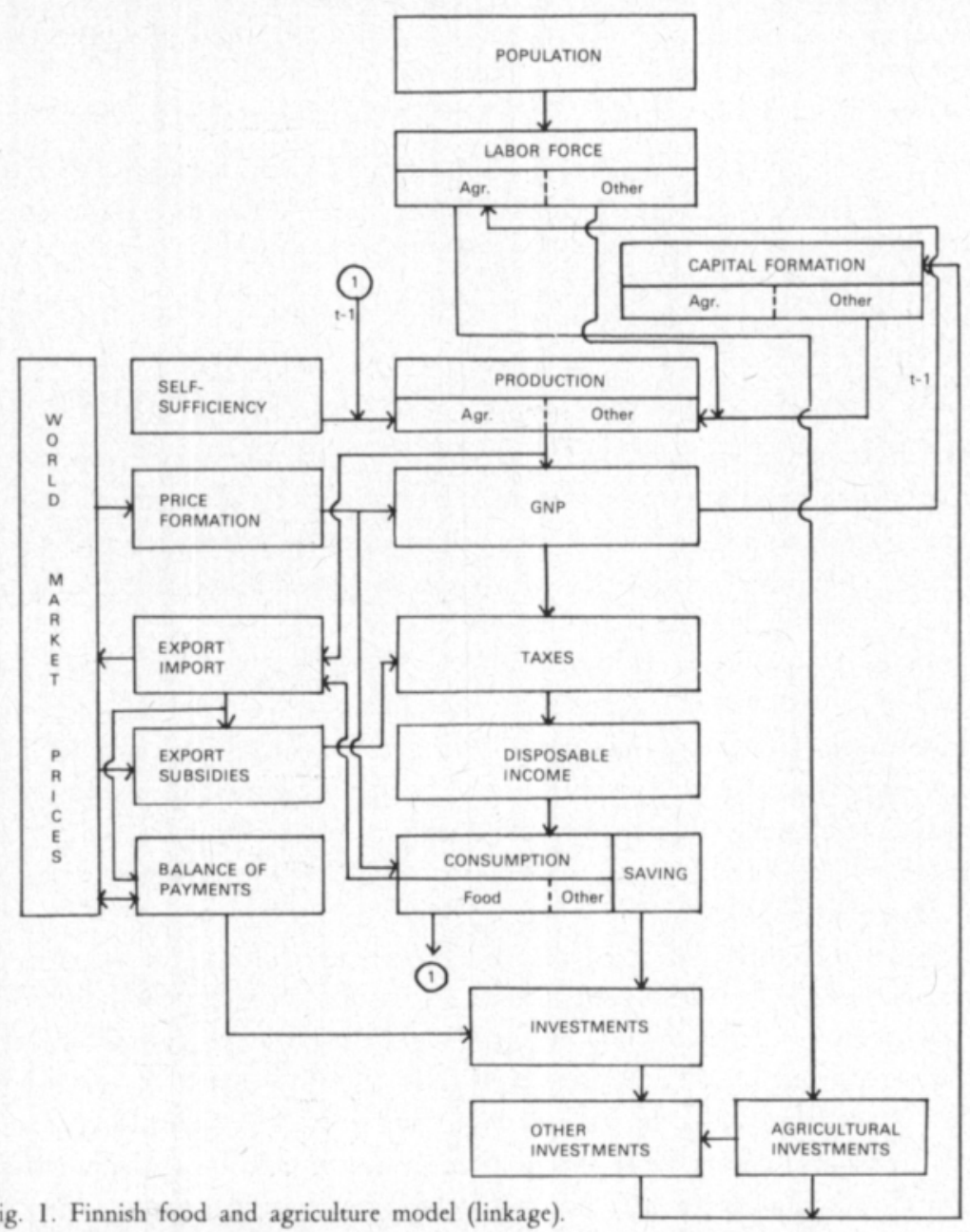




\section{Linkage model}

\section{Population}

For the whole population $\left(\mathrm{W}_{\mathrm{t}}\right)$ a simplified growth model:

2.1. $\mathrm{W}_{\mathrm{t}}=\left(1+\mathrm{k}_{1}\right)^{\mathrm{t}} \mathrm{W}_{\mathrm{o}}$

where $\mathrm{W}_{0}=$ the whole population in the base period

$k_{1}=$ the annual growth percentage

$\mathrm{t} \quad=$ time

may be sufficient since the growth is relatively slow and thus possible errors are small. Forecasts made by the Central Statistical Office may also be used (ANON. 1979).

The total labor force $\left(\mathrm{L}_{\mathrm{t}}\right)$ will be estimated as follows:

\section{2. $\mathrm{L}_{\mathrm{t}}=\mathrm{k}_{2} \mathrm{~W}_{\mathrm{t}}$}

where $k_{2}=$ the share of the labor force from the total population

or forecasts made by the Central Statistical Office will be applied.

The labor force of agricultural sector $\left(\mathrm{L}_{\mathrm{a}}\right)$ will be estimated by using demographic (Dem) and economic factors like the gross domestic product (GDP):

2.3. $\mathrm{L}_{\mathrm{at}}=\mathrm{f}\left(\mathrm{Dem}, \mathrm{GDP}_{\mathrm{t}-1}\right)$.

Studies made by the Marketing Research Institute of the Pellervo Society (HONKANEN et al. 1979) are up-to-date and may easily be applied to the model. al:

The labor force of the non-agricultural sector $\left(\mathrm{L}_{\mathrm{na}}\right)$ can be calculated as a residu-

2.4. $\quad \mathrm{L}_{\text {nat }}=\mathrm{L}_{\mathrm{t}}-\mathrm{L}_{\mathrm{at}}$

At this stage of the study, unemployment cannot be taken into account in the model thereby, to some extent, limiting the use of the model.

\section{Capital formation}

The volume of the capital $(\mathrm{K})$ in each sector is calculated as follows:

$$
\begin{aligned}
& \text { 3.1. } \mathrm{K}_{\text {nat }}=\left(1-\mathrm{d}_{1}\right) \mathrm{K}_{\text {nat-1 }}+\mathrm{I}_{\text {nat-1 }} \\
& \text { 3.2. } \mathrm{K}_{\mathrm{at}}=\left(1-\mathrm{d}_{2}\right) \mathrm{K}_{\mathrm{at}-1}+\mathrm{I}_{\mathrm{at}-1}
\end{aligned}
$$

where $d_{1}$ and $d_{2}$ are depreciation rates, and $I$ investments. 


\section{Production}

In this paper the list of commodities of the condensed IIASA model is applied (see Appendix I). There are 9 agricultural commodities and one non-agricultural commodity. A more detailed classification of commodities is used in some versions of the Finnish model since the aggregation of commodities done in the IIASA does not suit very well to us. E.g. pork, poultry and eggs are usually delt with separately. Different milk products are of great interest to Finnish agriculture and so, fluid milk, butter and cheese are also modelled separately in a version of the model. However, in order to keep this presentation as clear as possible, only the 10 commodity list is used in this article.

\subsection{Non-agricultural production}

The production of the non-agricultural sector $\left(Q_{n a}\right)$ is estimated by using CobbDouglas production function:

4.1 .

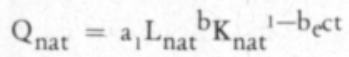

where $a_{1}, b$ and $c$ are parameters.

\subsection{Agricultural production}

The production model is, so far, intended for long term production planning. Since production has constantly exceeded consumption, several policy measures have been applied to curtail production. A solution to the excess supply problem seems to be to set selfsufficiency targets for individual products, which could be accepted by all parties concerned. Thus, in the model, production is determined by the selfsufficiency target (SS) and the lagged consumption (X):

\section{2. $\mathrm{Q}_{\text {ait }}=\mathrm{SS}_{\mathrm{it}} \mathrm{X}_{\mathrm{it}-1}$.}

Self-sufficiency (SS) can be changed linearly during a specified time period (TP):

4.3. $\quad \mathrm{SS}_{\mathrm{it}}=\mathrm{SS}_{\mathrm{i} 0}+\frac{\mathrm{SS}_{\mathrm{iT}}-\mathrm{SS}_{\mathrm{i} 0}}{\mathrm{TP}} \cdot \mathrm{t}$

4.4. $\quad \mathrm{SS}_{\mathrm{it}}=\mathrm{SS}_{\mathrm{iT}}$ when $\mathrm{t} \geqq \mathrm{TP}$

where $\mathrm{SS}_{\mathrm{iT}}$ is the desired self-sufficiency target for product $\mathrm{i}$ and $\mathrm{SS}_{\mathrm{io}}$ is the self-sufficiency for $\mathrm{t}=0$.

After the desired time period the self-sufficiency degree will be constant (Fig. 2). 
Fig. 2. The determination of the self-sufficiency target.

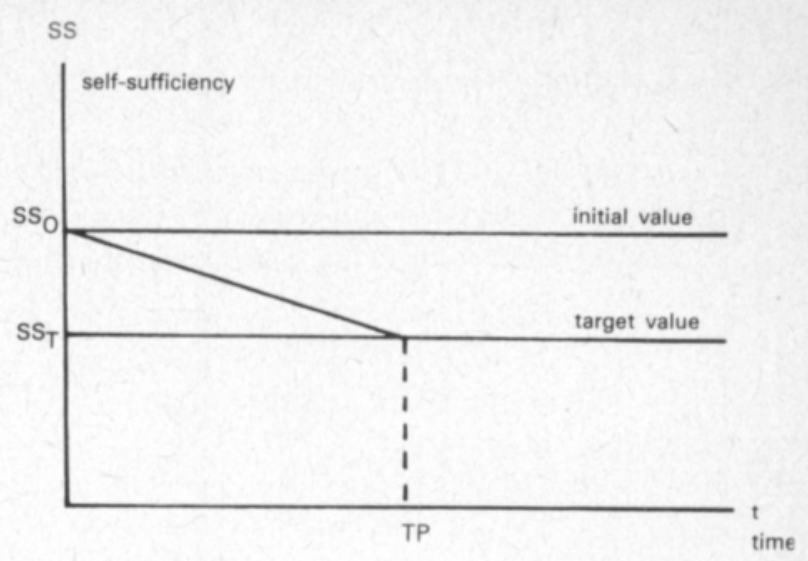

\section{Price formation}

The prices of major domestic products are internally determined and regulated, therefore, no relationships to the world market prices are assumed. In the first version of the model, the retail prices (PD) of the commodities from 1 to 6 are assumed to change annually by a constant rate $\left(\mathrm{r}_{\mathrm{it}}\right)$ :

5.1. $\mathrm{PD}_{\mathrm{it}}=\left(1+\mathrm{r}_{\mathrm{it}}\right)^{\mathrm{t}} \mathrm{PD}_{\mathrm{i} 0} \quad \mathrm{i}=1,2, \ldots, 6$

The prices of the commodities from 7 to 9 which are mostly exported and the price of the 10th commodity are assumed to depend on the world market prices $(\mathrm{PW})$ :

\section{2. $\mathrm{PD}_{\text {it }}=\mathrm{k}_{4 \mathrm{i}} \mathrm{PW}_{\mathrm{it}} \quad \mathrm{i}=7,8,9,10$}

The raw material prices (PRAW, producer prices) are related to the retail prices through price margins which depend on the price of the 10th commodity:

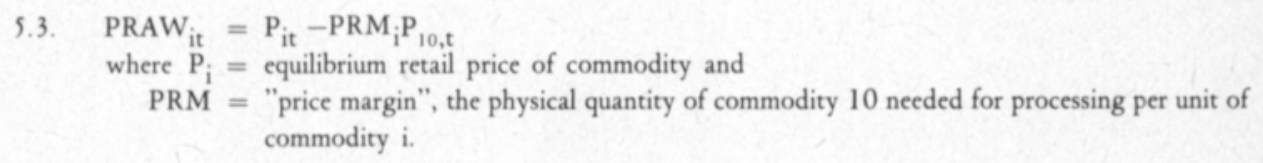

The price formation is very simplified since in reality retail and producer prices are often subsidized by different methods and price margins vary according to the demand-supply situation, etc. However, the model will be modified later on.

There is also an inconsistency between the demand and supply blocks since production is currently determined by the production targets and does not depend on prices at all. This production model can be revised. However, it may be thought that the policy practised by the Finnish government - including excise taxes, marketing fees, production ceilings, etc - is sufficient for realization of production targets. Moreover, the retail price policy must also reflect the aims of the production policy. 


\section{The value of production}

The gross domestic product (GDP) forms a central part of the model binding together different parts and regulating the growth of such factors as consumption. It is calculated by multiplying production by prices:

6.1. $\mathrm{GDP}_{\text {nat }}=\mathrm{PRAW}_{10 \mathrm{t}} \mathrm{Q}_{10 \mathrm{t}}$

6.2. $\mathrm{GDP}_{\mathrm{at}}=\sum_{1}^{9} \mathrm{PRAW}_{\mathrm{t}} \cdot \mathrm{Q}_{\mathrm{ait}}-\sum_{1}^{9} \mathrm{P} 4 \cdot \mathrm{Feed}_{\mathrm{it}}-\mathrm{k}_{\mathrm{s}} \mathrm{Y}_{\text {nat }}$

From the gross value of agriculture, the value intermediate products (feed, machinery, fertilizers, etc.) has to be subtracted. The use of other intermediate inputs than feed is thought (so far) to be a constant fraction of the non-agricultural production:

6.3. $\mathrm{GDP}_{\mathrm{t}}=\mathrm{GDP}$ nat $+\mathrm{GDP}_{\text {at }}$

\section{Taxation and disposable income}

Disposable income is needed for consumption functions, and is calculated by subtracting taxes from the gross domestic product (GDP). Taxes (T) are assumed to be a linear function of GDP:

7.1. $\mathrm{T}_{\mathrm{t}}=\mathrm{k}_{6}+\mathrm{k}_{7} \mathrm{GDP}_{\mathrm{t}}$

Disposable income (DI) is then:

7.2. $\mathrm{DI}_{\mathrm{t}}=\mathrm{GDP}_{\mathrm{t}}-\mathrm{T}_{\mathrm{t}}$

\section{Consumption}

Due to the IIASA's linkage system, a linear expenditure model is applied to estimate consumption:

8.1. $\quad \mathrm{P}_{\mathrm{it}} \mathrm{X}_{\mathrm{it}}=\mathrm{e}_{\mathrm{i}} \mathrm{DI} \mathrm{I}_{\mathrm{t}}$

where $\mathrm{X}_{\mathrm{i}}=$ the consumption of the commodity $\mathrm{i}$

$\mathrm{P}_{\mathrm{i}}=$ the retail price of the commodity $\mathrm{i}$

$\mathrm{e}_{\mathrm{i}}=$ the share of the commodity $\mathrm{i}$ of the total expenditure.

The model may be expanded so that it also includes the committed consumption.

The model has been further simplified by including investments and public expenditure together with the consumption of the 10th commodity (see FISCHER and FROHBERG 1980 , p. 85 ). Therefore, the consumption is a function of GDP minus the foreign debt (D):

$$
P_{i t} X_{i t}=e_{i}\left(G D P_{t}-D t\right)
$$


The expenditure shares are annually updated as follows

8.3. $\mathrm{e}_{\mathrm{i}, \mathrm{t}+\mathrm{t}}=\frac{\mathrm{e}_{\mathrm{i} 0}\left(\mathrm{~m}_{\mathrm{t}} / \mathrm{m}_{0}\right)^{v_{\mathrm{i}}}}{\sum_{\mathrm{k}=1}^{10} \mathrm{e}_{\mathrm{i} 0}\left(\mathrm{~m}_{\mathrm{t}} / \mathrm{m}_{\mathrm{o}}\right)^{v_{k}}}$

$$
\text { where } \mathrm{m}_{\mathrm{t}}=\frac{\sum_{\mathrm{i}=1}^{10} \mathrm{P}_{\mathrm{i} 0} \cdot \mathrm{x}_{\mathrm{it}}}{\mathrm{POP}_{\mathrm{t}}}
$$

$$
\mathrm{m}_{0}=\frac{\sum_{\mathrm{i}=1}^{10} \mathrm{P}_{\mathrm{i} 0} \cdot \mathrm{X}_{\mathrm{i} 0}}{\mathrm{POP}_{0}} \text { and } \mathrm{v}_{\mathrm{i}} \text { and } \mathrm{v}_{\mathrm{k}} \text { "income elasticities". }
$$

The expenditure shares are modified by taking into account the changes of real expenditure per capita (see e.g. FISCHER and FROHBERG, 1980, p. 90-91).

\section{Foreign trade}

Production and consumption determine foreign trade and the balance of the trade as follows:

9.1. $(\mathrm{Ex}-\mathrm{Im})_{\mathrm{it}}=\mathrm{Q}_{\mathrm{it}}-\mathrm{X}_{\mathrm{it}}$

9.2. $\mathrm{D}_{\mathrm{t}}=\mathrm{P}_{\mathrm{it}}^{\mathrm{w}}\left(\mathrm{Q}_{\mathrm{it}}-\mathrm{X}_{\mathrm{it}}\right)$

where $(E x-I m)=$ exports minus imports

Subsidies granted to agricultural product exports (Sub) which are important government finances are measured as follows:

9.3. $\mathrm{Sub}_{\mathrm{t}}=\left(\mathrm{PRAW}_{\mathrm{it}}-\mathrm{P}_{\mathrm{it}}^{\mathrm{w}}\right)^{\mathrm{Ex}} \mathrm{ait}_{\text {ait }}$

\section{Investments}

For the operation of the whole linkage model investments are crucial contributing to the capital volume, the increase of national income, and thus consumption, savings and investments.

The submodel for investments is as follows:

10.1. $S_{t}=s(G D P-D)$

10.2. $\mathrm{I}_{\mathrm{t}}=\mathrm{S}_{\mathrm{t}}$

10.3. $\mathrm{I}_{\mathrm{at}}=\mathrm{f}\left(\overline{\mathrm{Q}}_{\mathrm{at}}, \mathrm{L}_{\mathrm{at}}\right)$

10.4. $\mathrm{I}_{\text {nat }}=\mathrm{I}_{\mathrm{t}}-\mathrm{I}_{\mathrm{at}}$ where $s=$ share of savings 
Investments are financed by savings and foreign trade. Agricultural investment function is a function of the volume of agricultural production, agricultural labor force, and other factors. The investments of the non-agricultural sector are assumed to be the residual according to 10.4 .

\section{Agricultural submodel}

In order to simplify the handling of the whole model it has been divided here into two parts: a) the agricultural submodel and b) its linkage to the whole economy. This division is not necessary but it is more a convenience for programming. The linkage part which has been delt in the pragraphs $1-9$ can be taken as an independent model whereas the agricultural submodel obtains production, prices and agricultural labor force from the linkage model (Fig. 3). There is no feedback from the agricultural submodel to the linkage model.

The use of arable land and the structure of agriculture are the main points of attention in the agricultural submodel. A lot of time has been devoted to the construction of yield functions. The rising prices of fertilizers are expected to lower the use of fertilizers and therefore, yields may also drop. So far, per hectare yields have increased which has forced to draw a part of the land out of the production in order to curb the growth of overproduction. The soil bank system is one of focuses of the Finnish agricultural policy and therefore it has also a central role in the model.

Forestry is an essential part of a farm in Finland. E.g. agricultural investments depend to a large extent on the forestry income. So far, no model has been built for the linkage of forestry to the agriculture even though it is indicated by the Fig. 3 . That has to be done later on.

Environmental problems should also be included in the model, but so far no meaningful approach has been developed for that purpose.

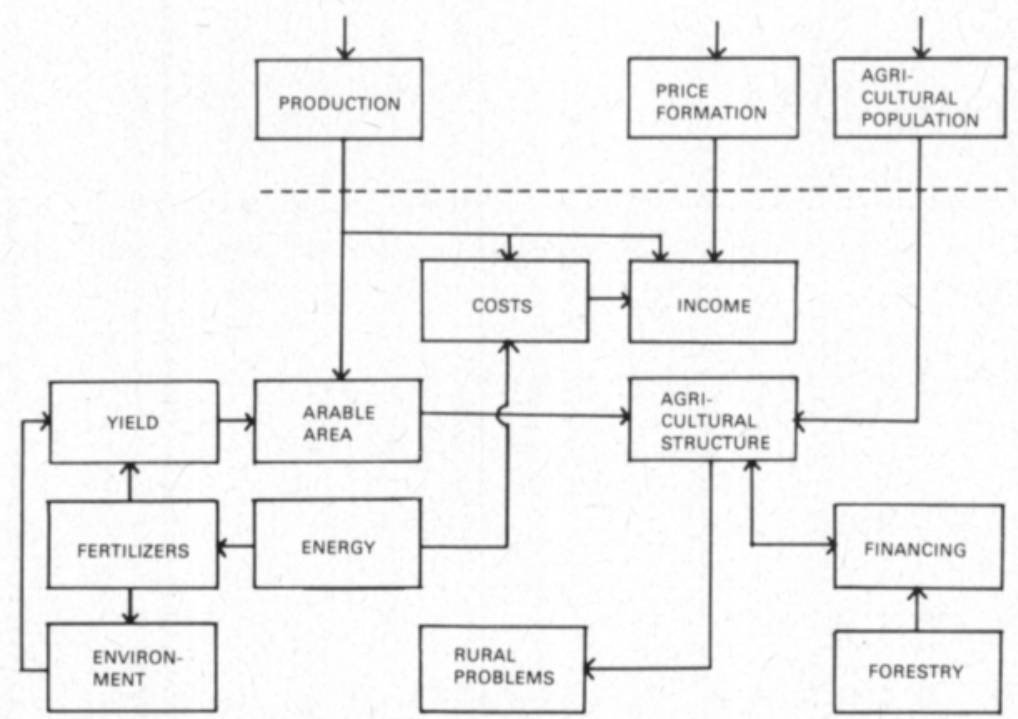

Fig. 3. Agricultural submodel of the Finnish food and agriculture model. 


\section{Plant production}

Per hectare yields are one of most important factors in the whole model. Given the arable land, it determines, to a large extent, the volume of agricultural production. The majority of plant production is utilized for animal production and only about 10-15 per cent is used for direct human consumption. Consequently, plant production determines also the possibilities for animal production (especially since little feed is imported).

The yield is considered to be a function of the use of nitrogen fertilizers $(\mathrm{N})$ and of the biological-technical development which is, in turn, a function of time $(\mathrm{t})$ :

\section{1. $\mathrm{Y}=\mathrm{f}(\mathrm{N}, \mathrm{t})$.}

The type of the yield function is rather difficult to determine since it should apply to the whole country and no corresponding statistics are available. The field experiments with respect to the use of fertilizers often give a scatter which supports the assumption of a parabolic yield function:

\section{2. $\mathrm{Y}=\mathrm{a}+\mathrm{bN}+\mathrm{cN}^{2}$.}

The biological-technological development factor incorporates all other factors effecting yield levels. Improvement of plants, use of advanced technology and planting methods, land improvements, use of herbicides etc. will increase yields even if the use of fertilizers falls due to the higher price of energy. All these factors will shift the yield function upwards to the right (Fig. 4).

This type of shift implies that the optimal use of fertilizers will also shift to the right with constant price of crops and fertilizers.

Since there is no variable which could be used for the biological-technological development, the time variable $(\mathrm{t})$ is applied.

Fig. 4. The effect of biologicaltechnological development.

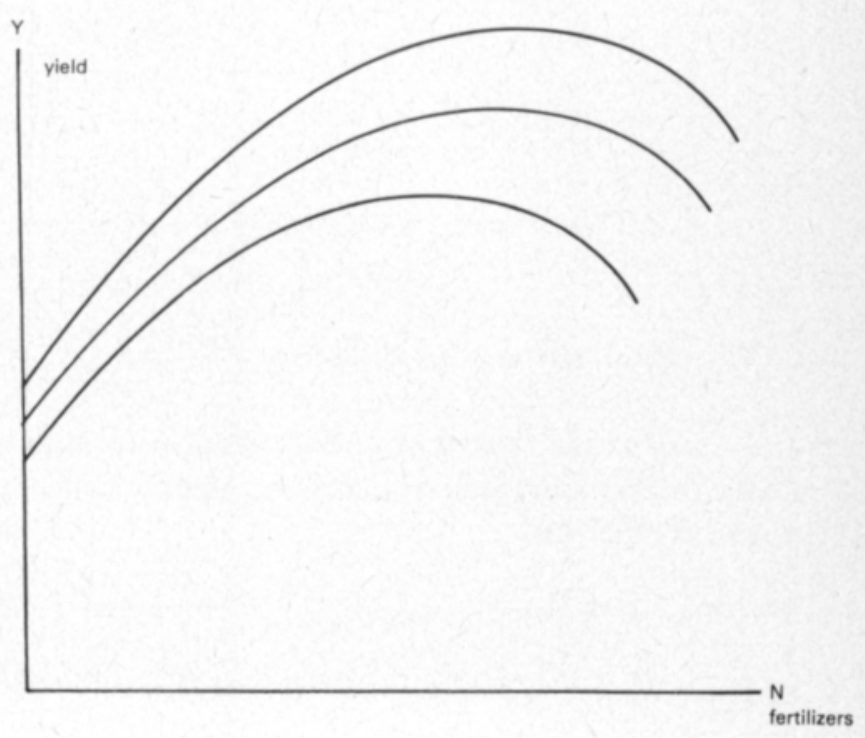


The biological-technological development may not be smooth, but rather irregular as certain innovations may stepwise improve yields. However, for the simulation purposes, we will assume the development to be diminshing with time (see e.g. HEIKKILÄ 1980, p. 53-54):

11.3. $Y=a_{0}+a_{1}(t-1)+b_{1} \ln \left(e+b_{2}(t-1)\right) N+c N^{2}$

where $e$ is the basic number of natural logarithms.

When $t=1$ we obtain the function 11.2. By letting $b_{1}=c=0$ we can derive the trend function:

11.4. $\mathrm{Y}=\mathrm{a}_{\mathrm{o}}+\mathrm{a}_{1}(\mathrm{t}-1)$.

The function 11.3. is applied for cereals and feedstuffs representing approximately 90 per cent of plant production. For other products function 11.4. is used since it is difficult to find any functional relationship between yields and use of fertilizers for those products or alternatively, factors other than fertilizers seem to be of greater influence than the use of fertilizers.

The level of fertilizer use is determined by the economic optimum:

11.5 .

$$
\frac{\mathrm{dy}_{\mathrm{i}}}{\mathrm{dx}}=\mathrm{P}_{\mathrm{f}} / \mathrm{PRAW}_{\mathrm{i}}
$$

where $P_{f}$ is the price of the fertilizers and PRAW is the producer price of the product $i$. The prices are obtained from the price formation submodel.

\section{Total acreage}

Total agricultural area (TAREA) has not changed significantly in recent years, even though some land has been used for infrastructure, since new land has been cleared. These factors can be taken into account as follows:

12.1. TAREA $_{t}=$ TAREA $_{t-1}+\mathrm{CLR}_{\mathrm{t}}-\mathrm{DEPR}_{\mathrm{t}}$

where CLR $=$ clearence of land and

DEPR $=$ depreciation of land

Land withdrawal and fallowing are calculated separately later on.

\section{Total agricultural production}

Agricultural production measured in feed units is needed for the estimation of the total cultivated area and is obtained by multiplying animal production with feeduse coefficients:

13.1. $\quad \mathrm{ARY}_{\mathrm{t}}=\sum \mathrm{FU}_{\mathrm{it}} \mathrm{Q}_{\text {ait }}$ where $\mathrm{FU}_{\mathrm{i}}$ is the number of feed units needed to produce one unit $(\mathrm{kg})$ of product $\mathrm{i}$. 
Feed use coefficients may be changed as a function of time:

13.2. $\mathrm{FU}_{\mathrm{it}}=\mathrm{f}(\mathrm{t})$.

Direct consumption of plant products can also be estimated in feed units:

13.3. $\operatorname{VAFU}_{\mathrm{t}}=\sum \mathrm{FU}_{\mathrm{i}} \mathrm{Q}_{\text {ait }}$

and thus an indicator for the total agricultural production in feed units (TRY) is obtained:

13.4. $\mathrm{TFU}_{\mathrm{t}}=\mathrm{AFU}_{\mathrm{t}}+\mathrm{VAFU}_{\mathrm{t}}$

Appropriate adjustments for consumption and production estimates have to be made however, in order to take into account waste, seed, etc.

\section{Cultivated area}

The acreage of each product (AR) is obtained by dividing production with the per hectare yield $\left(\mathrm{YHA}_{\mathrm{it}}\right)$ :

14.1. $\mathrm{AR}_{\mathrm{it}}=\frac{\mathrm{Q}_{\mathrm{it}}}{\mathrm{YHA}_{\mathrm{it}}}$

Bread grains and animal feed have to be treated separately in the model. Hay, silage and coarse grains are calculated in feed units and a yield function for this "combined" feed is estimated. In addition to the bread grains and feed yield functions, corresponding functions are estimated for potatoes, vegetables, fruits, sugar and oil seeds.

The total cultivated area (TAR) is:

14.2. $\mathrm{TAR}_{\mathrm{t}}=\sum \mathrm{AR}_{\mathrm{it}}$

and the soil bank withdrawal (SOIL), fallowing, or land clearance:

14.3. SOIL $_{\mathrm{t}}=\mathrm{TAREA}_{\mathrm{t}}-\mathrm{TAR}_{\mathrm{t}}$

\section{Structure of agriculture}

The model describes the structure of the whole agriculture giving the number of farms and their distribution according to the size. In addition, the structure is also described by production lines. The number and average size of farms and their distribution is calculated for each production line. A logarithmic normal distribution is applied for the discription of the size distribution.

The production submodel is the starting point for the structural model from where production is obtained. Linear trends have been applied for forecasting the development of the average of different farm categories. Since a separate article of the structural model is published in this journal there is no need to go into further details in this connection (see HASSINEN and KETTUNEN 1980; HASSINEN 1980). 


\section{The application of the model}

The model has been built so that all important parameters can be changed easily. For example, the user of the model can freely choose and change the self-sufficiency target of any product. Demand parameters, the growth of the fertilizer price, the growth rate of the population, etc., can be easily changed, which makes it possible to examine the effects of alternative policy actions or of different parameter estimates on the development of various factors. It its possible to generate many scenarios even so many that the utility of the model may become obscure. Therefore, our intention is to make a basic scenario, the most probable path of development. All other scenarios may then be compared to this basic scenario.

The basic scenario is also a forecast which will be utilized by the government. E.g. the forecasts of consumption (see ROUHIAINEN 1979) are needed for many purposes. Production forecasts may also be done by the model. They are needed among other things for the planning of production policy. Forecasts of per hectare yields of crops, which also can be generated by the model, are of great importance when the self-sufficiency of agricultural production is evaluated. The submodel may be applied independently e.g. for forecasting, but at the same time it is possible to calculate the development of all other factors and their interdependence which is usually neglected in a partial analysis.

Instead of changing the estimates of parameters, some users of the model would like to change the form of the function. This is also possible but not so easy as it partly requires programming.

The structure of the model is not yet completed. Very simple submodels are applied in some cases. The estimation of parameters needs more attention, too. The use of the model will certainly give new incentives for the development of the model which can be considered as a continuous process. The model covers the whole agriculture and therefore, it can never be completed. Any quantitative research may bring new ideas or submodels which may be linked to the model.

Acknowledgements. This study has been financially supported by the Ministry of Agriculture and Forestry and the Finnish Academy. The author wishes also to express his gratitude to the staff of the Agricultural Economics Research Institute which has helped in many ways in the research project. Especially I wish to mention Dr. Juhani Rouhiainen, Mr. Seppo Pursiainen, Mr. Tuomo Heikkilä, Mr. Seppo Hassinen and Ms. Merja Manninen. Dr. Antti Jaakkola from the Agricultural Research Centre deserves also my thanks for his assistance in building the plant production model.

\section{References}

ANON. 1979. Väestöennusteet 1978-2020. Tilastollisia Tied. 64. Tilastokeskus. Helsinki.

FISCHER, G. \& FROHBERG, K. 1980. Simplified national models. IIASA working paper WP-80-56. $113 \mathrm{p}$.

de HAEN, HARTWIG 1978. The food and agriculture model of the international institute for applied systems analysis. IIASA Res. Memor. RM-78-24. 21 p.

HASSINEN, SEPPO 1980. Maatalouden tuotantorakenteen kehitys. Maat. tal. tutk.lait. Tied. 66. Helsinki. $91 \mathrm{p}$. 
HASSINEN, SEPPO \& KETTUNEN, LAURI 1980. Simulation model for the structure of Finnish agriculture. J. Scient. Agric. Soc. Finl. 52: 456-467.

HEIKKILÄ, TUOMO 1980. Typpiväkilannoituksen taloudellinen optimaalisuus ja tulosten soveltaminen Suomen ravintotuotantomalliin. Pro gradu -työ. Hels. Yliop. Maanviljelystal. lait. Helsinki. $67+5$ p.

HONKANEN, SEPPO, TAURIAINEN, JUHANI \& VIHRIÄLÄ, VESA 1979. Maa- ja metsätalouden tyōvoiman määrän ja rakenteen kehitys vuosina 1980, 1985 ja 1990. Valtioneuvoston kanslian Julkaisuja 1979:2. Helsinki. $33+76$ p.

KETTUNEN, LAURI 1977. Ravinnontuotannon pitkän aikavälin ongelmia. Maat. tal. tutk.lait. Tied. 48, 2. Helsinki. 11 p.

KETTUNEN, LAURI 1978. Suomen ravintotuotantomalli. Helsinki (moniste). 54 p.

KEYZER, M. A. 1977. Analysis of a national model with domestic price policies and quota on international trade. IIASA Res. Memor. RM-77-19. 96 p.

ROUHIAINEN, JUHANI 1979. Changes in demand for food items in Finland 1250-77 with consumption forecasts for 1980, 1985 and 1990. Maat.tal tutk.lait. Julk. 40. Helsinki. 84 p.

Ms received September 10, 1980.

\section{SELOSTUS}

\section{Suomen ravintotuotantomalli}

\section{Lauri Kettunen}

Maatalouden taloudellinen tutkimuslaitos, Rukkila, 00001 Helsinki 100

Suomen ravintotuotantoprojektin tarkoituksena on selvittää

a) mitkä ovat maamme maatalouden ongelmat pitkällä aikavälillä

b) rakentaa matemaattinen malli, jolla voidaan kuvata maatalouden kehitystã ja joka sisältäã erilaisia kehitykseen vaikuttavia politiikkamuuttujia, sekä

c) tutkia minkälaisia politiikkatoimenpiteitã tarvitaan omavaraisuuden säilyttämiseksi pitkällä aikavälillä.

Malli rakennetaan myös niin, että se voidaan liittää Kansainvälisen sovelletun systeemianalyysin instituutissa (International Institute for Applied Systems Analysis, Laxenburg, Itävalta) kehitteillä olevaan maailmanlaajuiseen simulointimalliin, jonka tavoitteena on tutkia koko maapallon elintarvikeongelmia.

Tässã artikkelissa esitellään mallin ensimmäinen versio. Se on pääasiassa rekursiivinen simulointimalli, jossa vain lannoitteiden kāytön määrittämisessã on sovellettu optimointikriteerejä. Mallin perusvuotena on 1978 ja sen avulla voidaan maatalouden kehitystă simuloida aina vuoteen 2010. Parametrien estimaatit perustuvat aikaisempiin tai tätä varten tehtyihin tutkimuksiin, joskin monin paikoin on täytynyt käyttää subjektiivista harkintaa, koska muutoin mallin antamat tulokset tuntuvat täysin poikkeavan todennäköisestä kehityksestä.

Malli on monin paikoin hyvin yksinkertainen, mutta sitä on tarkoitus kehittää edelleen alustavan version kãytổstã saatavien kokemusten pohjalta. Syynā yksinkertaistuksiin on osittain a.o. kohtia koskevan tutkimuksen puute. Mutta jo nykyisessã muodossaan sen voi katsoa soveltuvan varsin hyvin mm. kulutuksen sekä tuotannon, ennen muuta satotasojen ennustamiseen. Sillã saadaan myös ennusteita pellon tarpeesta tulevaisuudessa. 
APPENDIX I. IIASA'S B-COMMODITY LIST - CONDENSED VERSION

Condensed Model

Detailed Model

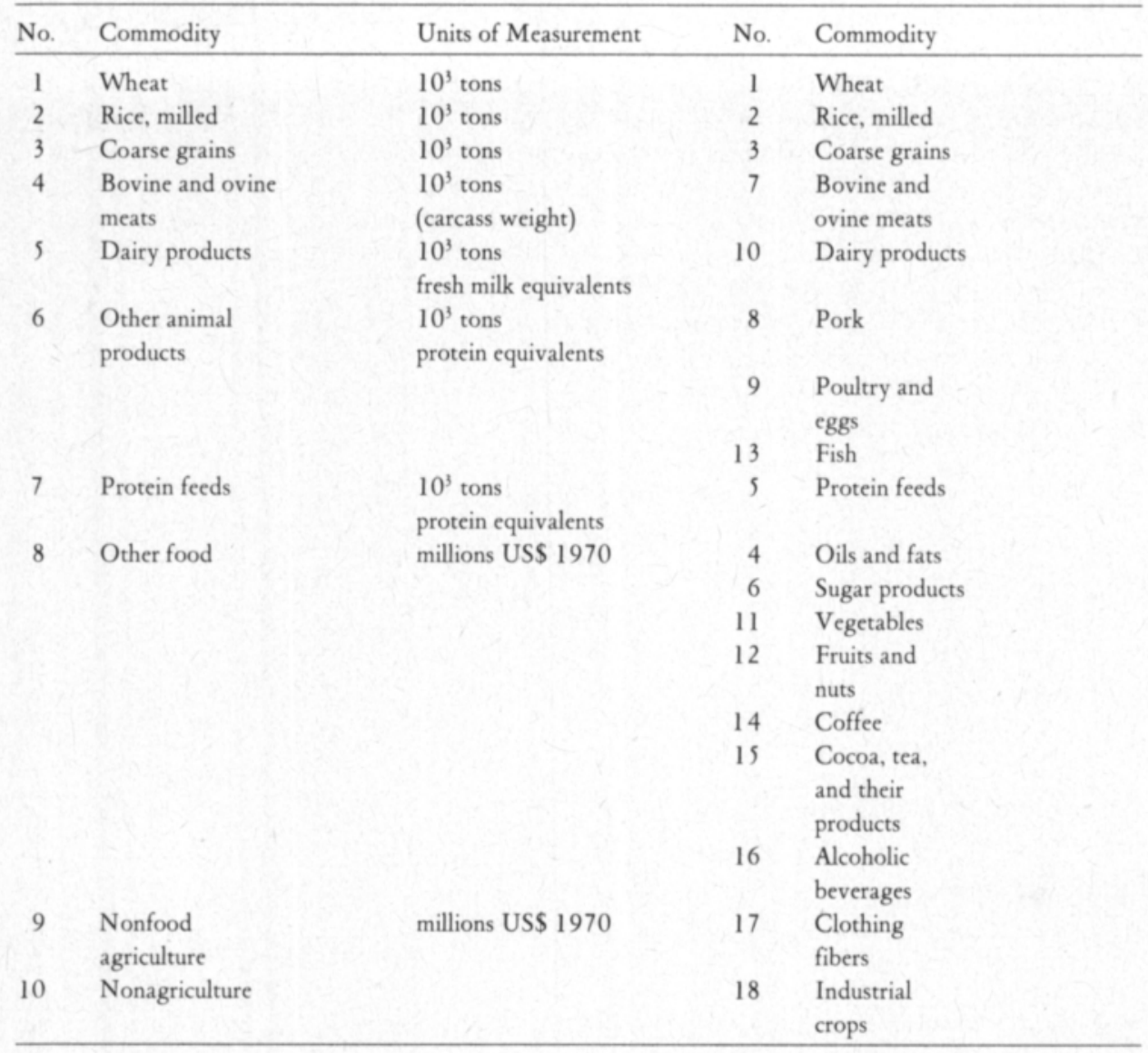

\section{APPENDIX II. THE LIST OF VARIABLES}

$\mathrm{W}_{\mathrm{t}} \quad=$ the whole population

$\mathrm{t}=$ the time variable

$\mathrm{L}=$ the labour force

Dem $=$ demographic factors

$\mathrm{GDP}=$ the Gross Domestic Product

$\mathrm{K}=$ the capital

I $\quad=$ investments

$\mathrm{Q}=$ the production

SS $\quad=$ the self-sufficiency ratio

$\mathrm{X} \quad=$ the consumption

TP $=$ the time period for the self-sufficiency target

$\mathrm{PD}=$ the retail price

$\mathrm{PW}=$ the world market price

PRAW $=$ the raw material price (producer price)

$\mathrm{P} \quad=$ the equilibrium retail price

PRM = the "price margin", the physical quantity at commodity 10 needed for processing per unit of commodity $i$ 


$$
\begin{aligned}
& \text { Feed }_{\mathrm{i}}=\text { the use of the commodity } \mathrm{i} \text { for feed } \\
& \mathrm{P}_{\mathrm{fe}} \quad=\text { the price of feed } \\
& \mathrm{T} \quad=\text { taxes } \\
& \text { DI }=\text { the disposable income } \\
& \text { D } \quad=\text { the foreign dept } \\
& \text { Ex } \quad=\text { the export } \\
& \text { Im }=\text { the import } \\
& \text { Sub } \quad=\text { subsidies } \\
& \mathrm{N} \quad=\text { the use of nitrogen fertilizer } \\
& \mathrm{Y}=\text { the yield (or YHA) } \\
& \mathrm{P}_{\mathrm{f}} \quad=\text { the price of the fertilizers } \\
& \text { TAREA }=\text { the total agricultural area } \\
& \text { CLR = the clearance of land } \\
& \text { DEPR }=\text { the depreciation of land } \\
& \mathrm{FU} \quad=\text { feed unit (equal to one } \mathrm{kg} \text { of barley) } \\
& \text { AFU = the animal production (in feed units) } \\
& \text { VAFU }=\text { the direct consumption of plant products (in feed units) } \\
& \text { TFU = the total agricultural production (in feed units) } \\
& \text { AR = the acreage of each product } \\
& \text { TAR }=\text { the total cultivated area } \\
& \text { SOIL = the excess of the land (soil bank, fallowing, etc.) }
\end{aligned}
$$

